\title{
Basement structures over Rio Grande Rise from gravity inversion
}

\author{
Renata Regina Constantino a, *, Peter Christian Hackspacher ${ }^{b}$, Iata Anderson de Souza ${ }^{c}$, \\ Iago Sousa Lima Costa ${ }^{\mathrm{d}}$ \\ a Universidade Estadual Paulista (UNESP), IGCE, Rio Claro, C.P. 178, CEP 13506-900, SP, Brazil \\ ${ }^{\mathrm{b}}$ Universidade Estadual Paulista (UNESP), DPM/IGCE, Rio Claro, C.P. 178, CEP 13506-900, SP, Brazil \\ ${ }^{\mathrm{c}}$ Universidade Estadual Paulista (UNESP), UNESPetro/IGCE, Rio Claro, C.P. 178, CEP 13506-900, SP, Brazil \\ d Serviço Geológico do Brasil - CPRM/DISEGE, Brazil
}

\section{A R T I C L E I N F O}

\section{Article history:}

Received 29 November 2016

Received in revised form

17 January 2017

Accepted 14 February 2017

Available online 17 February 2017

\section{Keywords:}

Basement

Rio grande rise

Gravity inversion

\begin{abstract}
A B S T R A C T
The basement depth in the Rio Grande Rise (RGR), South Atlantic, is estimated from combining gravity data obtained from satellite altimetry, marine surveys, bathymetry, sediment thickness and crustal thickness information. We formulate a crustal model of the region by inverse gravity modeling. The effect of the sediment layer is evaluated using the global sediment thickness model of National Oceanic and Atmospheric Administration (NOAA) and fitting the sediment compaction model to observed density values from Deep Sea Drilling Project (DSDP) reports. The Global Relief Model ETOPO1 and constraining data from seismic interpretation on crustal thickness are integrated in the inversion process. The modeled Moho depth values vary between 6 and $27 \mathrm{~km}$ over the area, being thicker under the RGR and also in the direction of São Paulo Plateau. The inversion for the gravity-equivalent basement topography is applied to gravity residual data, which is free from the gravity effect of sediments and from the gravity effect of the estimated Moho interface.

We find several short-wavelengths structures not present in the bathymetry data. Our model shows a rift crossing the entire Rio Grande Rise deeper than previously presented in literature, with depths up to $5 \mathrm{~km}$ in the East Rio Grande Rise (ERGR) and deeper in the West Rio Grande Rise (WRGR), reaching $6.4 \mathrm{~km}$. An interesting NS structure that goes from $34^{\circ} \mathrm{S}$ and extends through de São Paulo Ridge may be related to the South Atlantic Opening and could reveal an extinct spreading center.
\end{abstract}

() 2017 Elsevier Ltd. All rights reserved.

\section{Introduction}

The ocean basement is presumed to be oceanic basaltic crust created at mid-ocean ridges and its knowledge is crucial in many applications of geosciences, as the basement, rather than the ocean bottom, is representative of the tectonic situation and history of a specific area (Braitenberg et al., 2006). Due to continuous sedimentation over oceanic areas, morphologic features of the basement can be buried and features of low amplitude will be the first ones to disappear, distorting the tectonic framework (Constantino and Molina, 2014). Therefore, a flat ocean bottom may hide a completely different tectonic situation of lineaments, tilted crustal blocks and ridges, which can only be observed directly on the

\footnotetext{
* Corresponding author.

E-mail addresses: renata@iag.usp.br, renataconstantinobarrella@gmail.com (R.R. Constantino), phack@rc.unesp.br (P.C. Hackspacher), iataas@rc.unesp.br (I.A. de Souza), iago.costa@cprm.gov.br (I.S. Lima Costa).
}

basement.

The structural elements of the basement can be useful for understanding the opening and formation of the oceans, as it can reveal both extinct and active spreading axis. Manifold other applications can be cited: the study of plate tectonic movement from hot spot traces, the statistics of seamount populations and the interpretation of magnetic anomalies over oceanic areas in terms of the magnetic anomaly stage (Braitenberg et al., 2006).

Bathymetric models obtained by inversion of satellite-derived gravity data integrated with shipborne bathymetric information can be found in the literature, as in Smith and Sandwell (1997) and Sandwell and Smith (2001). The approach we are using in this paper is quite similar, but differently from inverting the gravity signal for the ocean bottom, the information contained in the gravity field is entirely used. Where there is a sedimentary blanket covering the basement, the gravity anomaly may contain a high spatial frequency signal corresponding to the morphology of the buried structures, which is dismissed in the inversion calculation 
for bathymetry, but considered for the basement.

For marine geology studies that aim to investigate tectonic features in areas where seismic data is unavailable, the interpretation of the gravity field can be a great solution. A good example of such a situation is given in the Rio Grande Rise (RGR). Most of the geological knowledge of the RGR comes from early Deep Sea Drilling Project (DSDP) reports (Barker, 1983), the reflection seismic lines tied to DSDP drillings interpreted by Gamboa and Rabinowitz (1981, 1984), and refraction/reflection seismic surveys conducted by Leyden et al. (1971). Nevertheless, the geology of the basement is poorly known.

The methodology we propose was previously applied successfully for different oceanic areas, like South China Sea (Braitenberg et al., 2006) and Santos Basin (Constantino et al., 2016).

In this paper we determine the basement topography for RGR from the combined analysis of the satellite gravity anomaly field, the bathymetric model, the sediment thickness model and crustal thickness information. As a by-product of our analysis, we determine the Crust-Mantle interface (Moho depth). The main features of the gravity anomaly field correlated to the basement, is discussed.

\section{Regional setting}

The RGR, one of the major large igneous provinces (LIPs) in the South Atlantic Ocean, extends between $28^{\circ}$ and $34^{\circ} \mathrm{S}$ and $28^{\circ}$ and $40^{\circ} \mathrm{W}$ (Gamboa and Rabinowitz, 1984) and has an isolated position, possible due to a westward migration of the Mid-Atlantic spreading axis during the Late Cretaceous (70 Ma) (Rohde et al., 2012). The bathymetry over the area (Fig. 1), shows depths ranging from $500 \mathrm{~m}$ up to $6200 \mathrm{~m}$. In the RGR, it varies from $800 \mathrm{~m}$ in the shallower area to nearly $5400 \mathrm{~m}$ in the NW rift structure that crosses the rise.

According to Rohde et al. (2012), seafloor morphology indicates that the RGR formed adjacent to the Walvis Ridge and was then separated from it through mid-ocean ridge spreading. It is divided into two different morphological units, the Western Rio Grande Rise (WRGR), which is a large elliptical plateau with average depth of $2000 \mathrm{~m}$ and the Eastern Rio Grande Rise (ERGR), which is approximately a north-south trending that runs parallel to the present day Mid-Atlantic Ridge axis (Gamboa and Rabinowitz, 1984). The WRGR was affected in Eocene times by a magmatic episode, giving rise to guyots and seamounts responsible for the high elevations reaching up to $700 \mathrm{~m}$ below sea level at the present time (Ussami et al., 2012). WRGR and ERGR are truncated by a NW-SE trending rift, surrounded by seamounts and guyots. A detailed description of this tectonic feature, which is approximately $1 \mathrm{~km}$ deep and filled with sediments, is presented in Mohriak et al. (2010).

\subsection{Basement characteristics of the RGR}

Little is known about the geology of the basement in the RGR region. Less is known about its depth. Although some DSDP sites on the RGR have been drilled, only site $516 \mathrm{~F}$ (leg 72) has reached the basement (Fig. 1). Rocks drilled along this site and over the main platform, consist of tholeiitic basalts, presenting a trace-element chemistry characteristic of transitional mid-ocean ridge basalts (Thompson et al., 1983). Nevertheless, the guyots and seamounts are composed of Eocene age alkaline basaltic rocks typical of oceanic islands (Fodor et al., 1977). From the paleobathymetry of the rise derived through sediment and stratigraphic data and through its subsidence history, it is suggested that the RGR was initially very shallow and parts of it might even have been above sea level during Santonian to Campanian (Detrick et al., 1977). From site 21 (leg 3) at ERGR the age was estimated between 84 and $75 \mathrm{Ma}$ (O'Connor and Duncan, 1990), however, the drilling did not reach the basement at this site.

Evidences using seismic interpretation to define the basement in RGR can be found somewhere in the literature (Kumar, 1979; Barker, 1983; Gamboa and Rabinowitz, 1984; Mohriak et al., 2010), but even in these sparse cases, the actual surface that is interpreted is the acoustic basement, defined as the deepest observable reflector in the seismic reflection profiles, which might not actually represent the base of the sediments. In oceanic areas, basement is presumed to be oceanic basaltic crust created at midocean ridges, however, in some cases, strongly reflective chert layers and mid plate volcanic rocks mask the underlying oceanic crust. According to Kumar (1979) the acoustic basement over RGR is not clearly visible on seismic records due to a reflector composed of Santonian-age limestone that masks the acoustic basement under most of the rise.

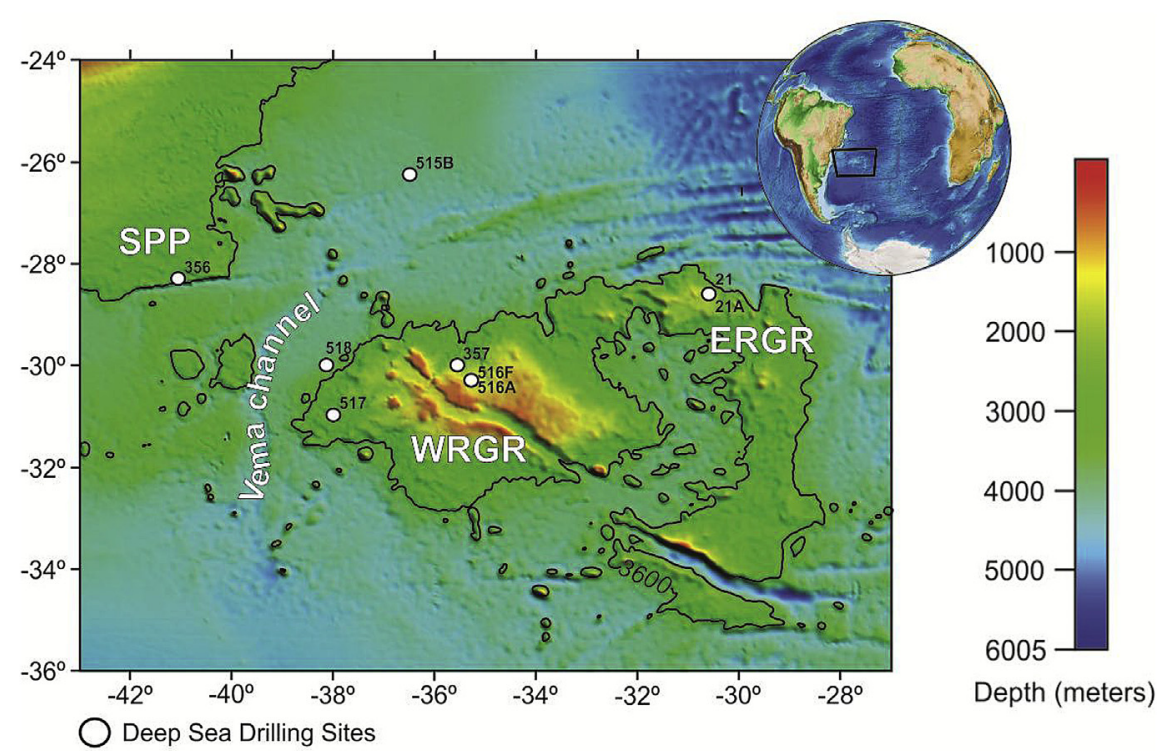

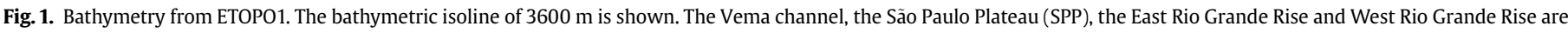
also represented. White circles are Deep Sea Drilling Project Legs. 


\section{Data sets}

Our study is based on gravity data, bathymetry measurements, sediment thickness and seismic crustal thickness evaluation. We use the global satellite-derived gravity grid of Sandwell et al. (2014). The accuracy of the global marine gravity model is 2 mGal, two times more accurate than previous models available in the literature.

The observed gravity anomaly is shown in Fig. 2, and for orientation, the $3600 \mathrm{~m}$ bathymetric isoline are added into this and all the other maps. The satellite-derived gravity field is a $1^{\prime} \times 1^{\prime}$ 'grid. The RGR is associated with a major NW-SE trending regional positive free-air anomaly on which there is an evident feature marked by a negative anomaly. We use the bathymetry grid extracted from ETOPO1 (Amante and Eakins, 2009), a $1^{\prime} \times 1^{\prime}$ grid digital elevation model. The sediment thickness model was taken from the "Total Sediment Thickness of the World's Oceans and Marginal Seas, Version 2". The digital total sediment thickness database was compiled by the National Geophysical Data Center (NGDC) of NOAA (National Oceanic and Atmospheric Administration) and has a resolution of 5 arc-min. The gridded data estimate the total sediment thickness, in meters, from the seafloor to the top of acoustic basement (Divins, 2003). All grids were sampled for an interval of $4 \mathrm{~km}$ using UTM projection.

We also have considered all density values available for the area from drilling logs of DSDP: Leg 3, sites 21, 21A; Leg 39, sites 356, 357; Leg 71, sites 515B, 516A, 516F, 517, 518 (Fig. 1). Other data we used for our model include Moho depth values from Leyden et al. (1971) and Moho depth punctual values interpreted from seismic reflection lines provided by the Geological Survey of Brazil (CPRM).

\section{Methodology}

The short-wavelength part of the gravity field over oceanic areas has been used with great success to formulate global bathymetric models (e.g., Smith and Sandwell, 1997; Sandwell and Smith, 2001) and this can be very useful where the direct measurements of bathymetry are not available or have not been fulfilled. The goal of this study is to use the entire gravity signal to the recovery of the basement structure, which will coincide with the bathymetry only where there is no sedimentary cover. In order to reach our goal, we propose a methodology based on the previous works Braitenberg et al. (2006) and Constantino et al. (2016). The structure of the method is divided into three main steps:

\subsection{Step 1}

The first step consists of gravity inversion to model Moho depth variations. For the Moho undulations to be inverted from the gravity data, the gravity values are corrected for the bathymetry (Bouguer correction) and for the sediment thickness variations. The residual field is inverted by applying an iterative constrained inverse modeling (Braitenberg et al., 1997). For this purpose, only the long wavelength part of the observed gravity field is used. The method requires some starting parameters, including the reference depth of the interface, and also the density contrast across the interface (between crust and mantle). To constrain the inversion results, Moho depth values obtained by seismic interpretation should be used.

\subsection{Step 2}

The purpose of this step is to isolate the observed gravity anomaly from the gravity signal of the Moho obtained in step 1 and from the sediments. The gravity effect of the Moho is calculated by Parker algorithm (Parker, 1972). The resulting field $\left(g_{M o h o}\right)$ and the gravity effect of sediments $\left(g_{\text {sed }}\right)$ are subtracted from the observed gravity anomaly:

$g_{\text {res }}=g_{\text {obs }}-g_{\text {Moho }}-g_{\text {sed }}$

The residual field $\left[(g)_{\text {res }}\right)$ is presumed to be the gravity field of the basement and it is used for inversion in the last step.

\subsection{Step 3}

In the last step, the residual gravity field $\left[(g)_{\text {res }}\right)$ is inverted and the gravity-equivalent basement topography is calculated. When inverting for the bathymetry from the gravity signal, the density contrast between crust and water is used. In order to be able to use this same density difference also for the inversion of the basement,
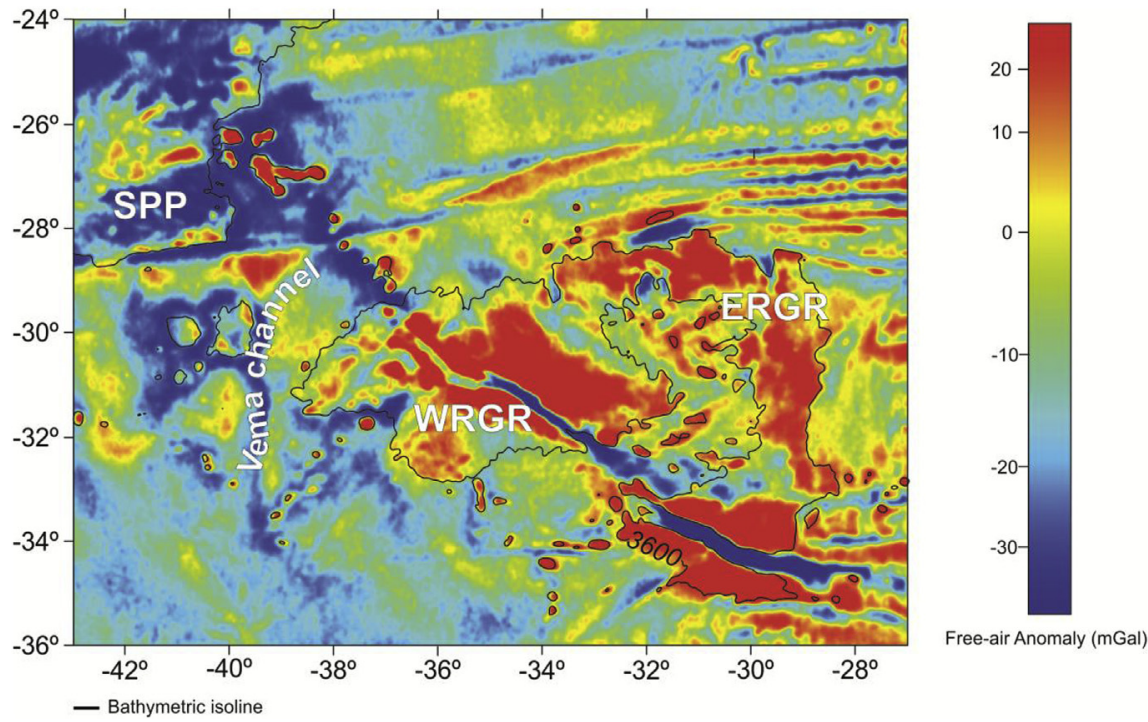

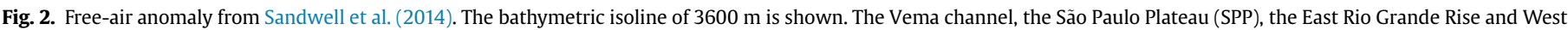
Rio Grande Rise are also represented. 
the sediments-gravity effect must be calculated against the reference density of water. The sediments can be regarded as a surplus mass relative to water (Braitenberg et al., 2006). The diagram displayed in Fig. 3 summarizes the tree steps discussed above.

\section{Results}

We calculated the gravity-equivalent basement topography following the steps explained above and illustrated in Fig. 3. The first step involves correcting the gravity field for the effect of the sedimentary cover. The gravity effect of the sediments can be calculated by the Parker algorithm with a single density contrast along the interface, but for more realistic results, the compaction with depth must take into account. In this paper, we have considered a linear relationship between density and depth, calculated according to Wienecke et al. (2008):

$\rho(z)=\rho_{\text {top }}+\frac{\left(\rho_{\text {low }}-\rho_{\text {top }}\right) h_{\text {sed }}}{\left(h_{\text {low }}-h_{\text {top }}\right)}$

where $\rho_{\text {top }}$ and $\rho_{\text {low }}$ are respectively the maximum and minimum density of the layer, calibrated from DSDP data and set between 2700 and $2800 \mathrm{~kg} / \mathrm{m}^{3}, h_{\text {sed }}$ is the thickness of the sedimentary cover, $h_{\text {low }}$ is the layer inferior depth and $h_{\text {top }}$ is the superior layer depth (commonly set in zero). The gravity effect of the sediments is calculated by applying Parker algorithm in a series of thin sheets (10 $\mathrm{m}$ thickness) with laterally variable density, calculated with equation (2). The sediment cover contributes an amount about 25 mGal to the gravity signal, being higher in the transition between the RGR and the São Paulo Plateau, where the sedimentary cover is thicker. This field is subtracted from Bouguer anomaly, resulting in the sediment corrected Bouguer anomaly, displayed in Fig. 4.

The Moho depth is calculated by inversion of the sediment corrected Bouguer anomaly. For the inversion, we set a constant density contrast of $450 \mathrm{~kg} / \mathrm{m}^{3}$ across the interface and a reference depth of $26.5 \mathrm{~km}$. These parameters are chosen inverting the field for different combinations (varying density contrast from 300 to $600 \mathrm{~kg} / \mathrm{m}^{3}$ and reference depth from 20 to $35 \mathrm{~km}$ ) and calculating the root mean square (RMS) difference with seismic punctual depth values (Fig. 5). The best agreement (1.17 km RMS) has determined the pair of values cited above. A cutoff wavelength of $123 \mathrm{~km}$ was estimated from the decay of the amplitude spectrum of the gravity field (Russo and Speed, 1994). The Moho depth is displayed in Fig. 5. It is clearly defined two regions where the Moho is deepest, giving the impression that these areas are being outlined by the bathymetric isoline of $3600 \mathrm{~m}$. Under RGR, the Moho varies from $15 \mathrm{~km}$ to $23 \mathrm{~km}$, and under the transition to São Paulo Plateau, it varies between $15 \mathrm{~km}$ and $27 \mathrm{~km}$. In the surrounding area, it shallows to a depth about $6 \mathrm{~km}$.

We now calculate the gravity field of the Moho and subtract it and the gravity field of the sediments from the gravity anomaly, obtaining the residual field $\left(g_{\text {res }}\right)$, which is inverted to result in the gravity-equivalent basement topography. The density contrast for this inversion is set in $1870 \mathrm{~kg} / \mathrm{m}^{3}$ that correspond to the density contrast of crust to water, using the above crustal density of $2900 \mathrm{~kg} / \mathrm{m}^{3}$ and the water density $1030 \mathrm{~kg} / \mathrm{m}^{3}$. The reference depth is set to zero level and all wavelengths contained in the gravity field are taken into account. The resulting gravity-equivalent basement is shown graphed as contour lines in Fig. 6 and as a 3-D relief in Fig. 7. Compared to the ETOPO1 bathymetry, it presents a greater amount of small-scale features and is quite deeper, mainly where the sediment is thicker.

\section{Discussion}

We have used the gravity signal to build a gravity-equivalent basement topography that contains features buried by sediments. Inspection of Figs. 1 and 6 reveals some remarkable topographic features that are clearly better defined in the basement model than in the bathymetry. Also, features not present in the bathymetric model were found in the basement, and we assume that they are covered by the sediment package. The most evident of these features are pointed in Fig. 6 and discussed above.

A prominent feature along the Rio Grande Rise (RGR) concerns a large central NW-SE rift that crosses the entire rise. The basement model shows this rift much deeper, with differences that exceed $1000 \mathrm{~m}$ in relation to the bathymetric model. In the central part of the rise, were well 516F was drilled (Fig. 1), it is the only point that

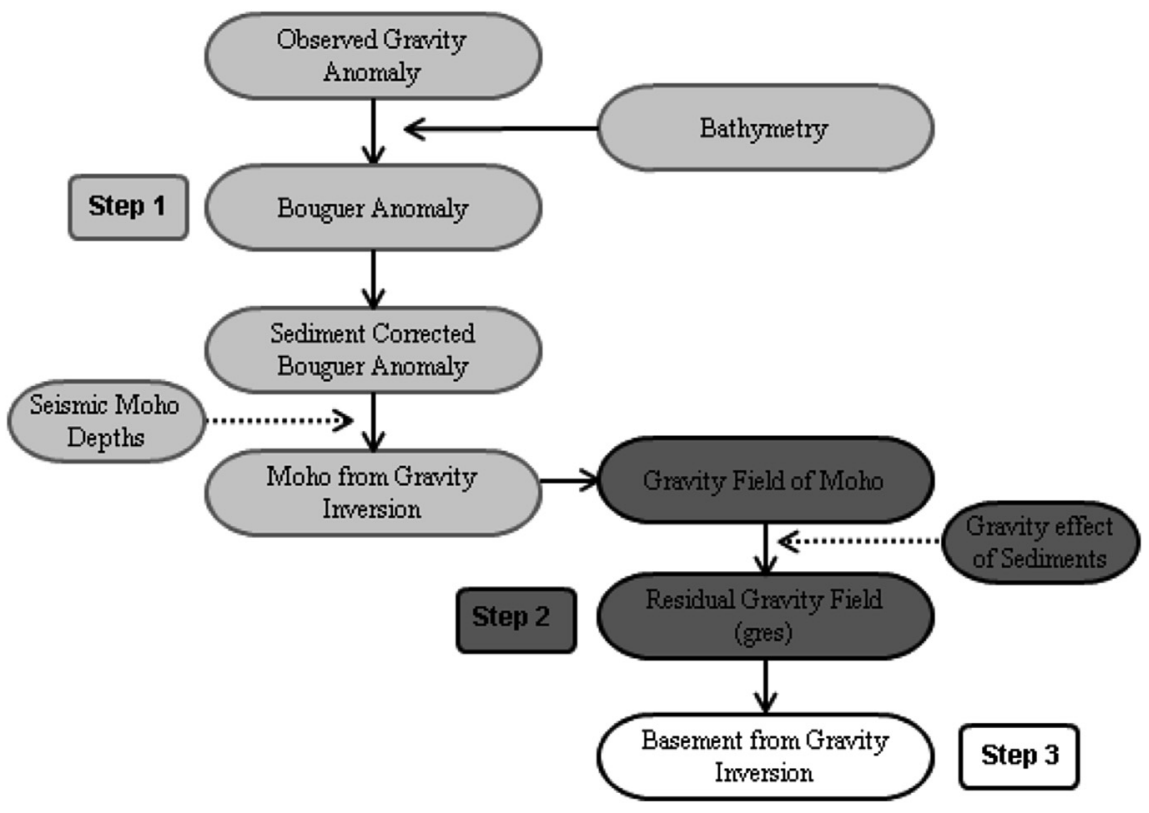

Fig. 3. Flowchart illustrating the 3 different steps of the modeling and inversion procedure. 

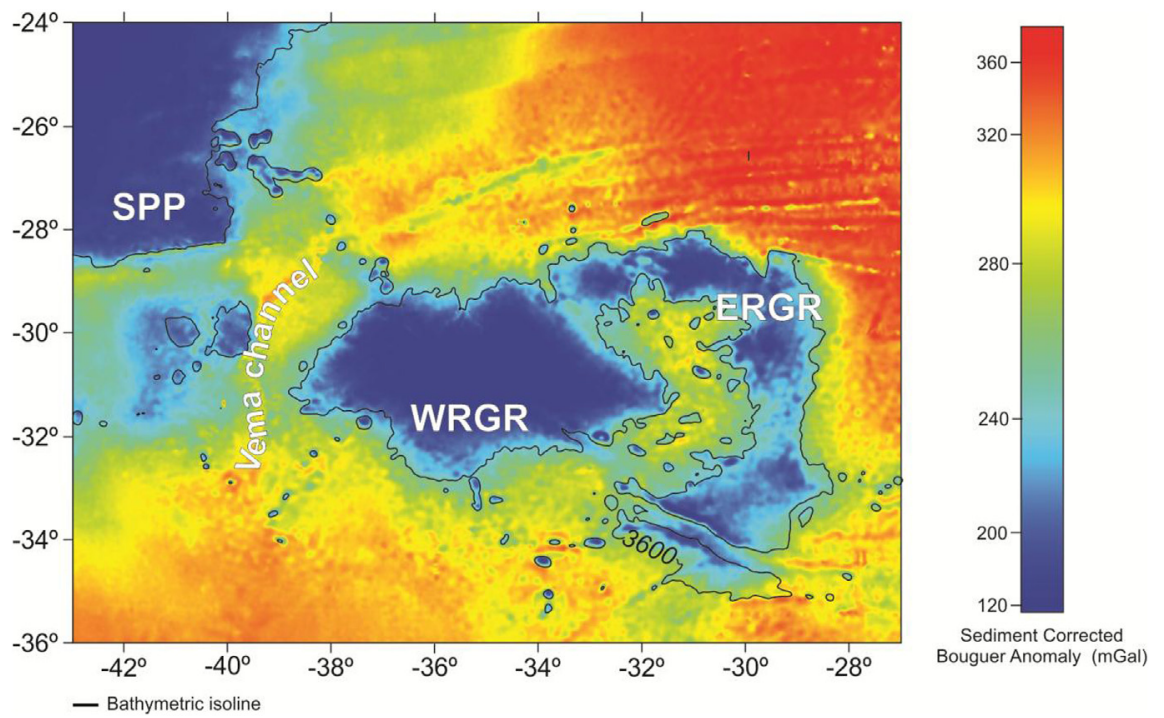

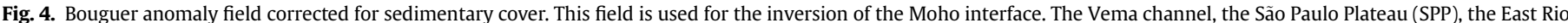
Grande Rise and West Rio Grande Rise are also represented.

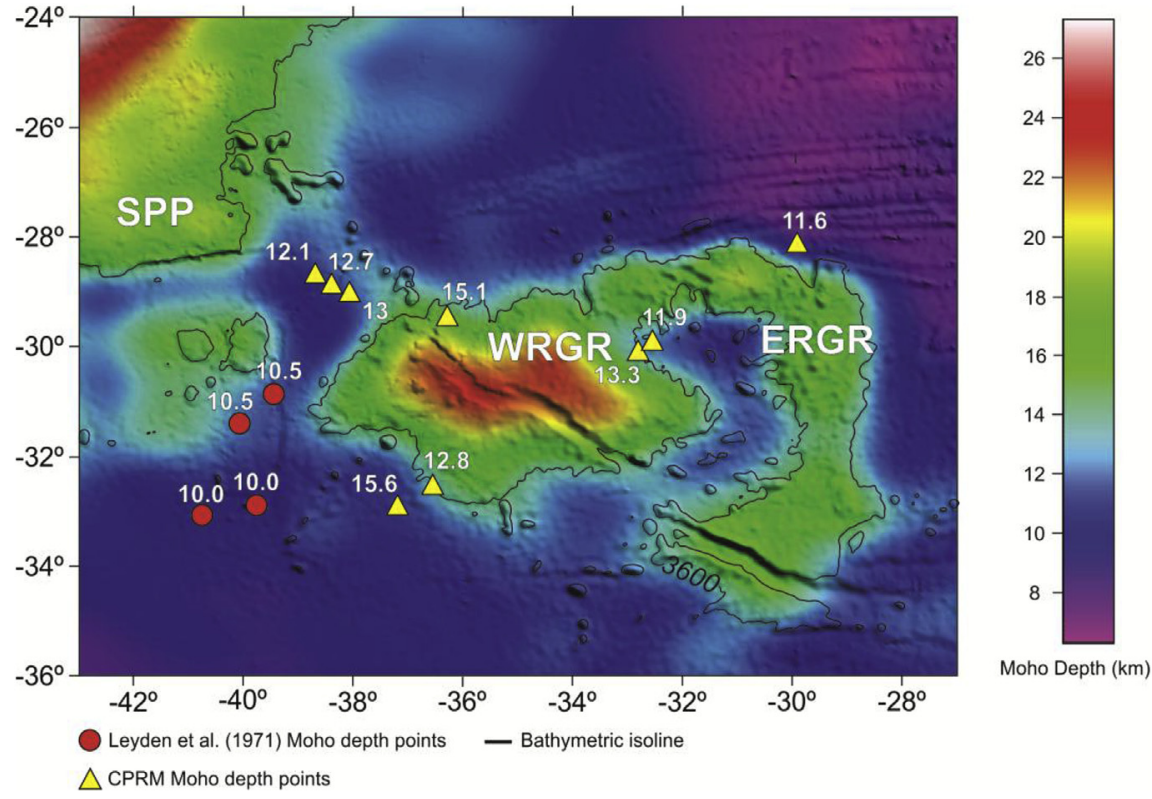

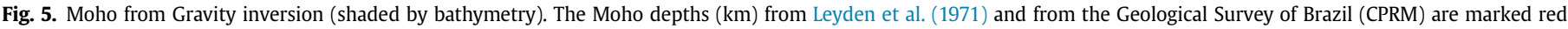
circles and yellow triangles, respectively. (For interpretation of the references to colour in this figure legend, the reader is referred to the web version of this article.)

we can compare and constrain our model, and a small difference of approximately $9 \mathrm{~m}$ between the depth registered in the drill and the gravimetric basement is found.

The Rio Grande Rise is associated with the east-west-trending fracture zones, clearly identified in the basement model. The Rio Grande Fracture Zone continues towards the platform as the Florianópolis High and landward as the São Paulo Ridge (SPR) (Basseto, 1996). At this point, a well-defined trough is seen. These was previously described by Kumar et al. (1977) as an expression of an east-west trending fracture zone that can be traced from track to track from $42^{\circ} \mathrm{W}$ to $38^{\circ} \mathrm{W}$ and even farther eastward to $29^{\circ} \mathrm{W}$ longitude. Tectonic features such as seamounts and guyots of low amplitude are identified. Such features are concentrated near the Rio Grande Rise fracture zone and surrounding the lineaments of Chuí, Porto Alegre and Cruzeiro do Sul. The most significant is the Jean Charcot seamounts that despite of appearing in the bathymetry are much more evident in the basement.

A curious and interesting NS structure apart from Vema channel is interpreted in the basement (Figs. 6 and 7), extending from $34^{\circ} \mathrm{S}$, vanishing in the trough and continuing in the São Paulo Ridge. Based on this evidence, it is possible that this feature was formed before the São Paulo Ridge and has a relationship with the Atlantic opening. It could indicate an extinct spreading center, previously discussed by Kumar (1979). For a more specific discussion, additional information such as age of the ocean floor and magnetic anomalies is needed. Unfortunately, this goes beyond the scope of the present paper. 

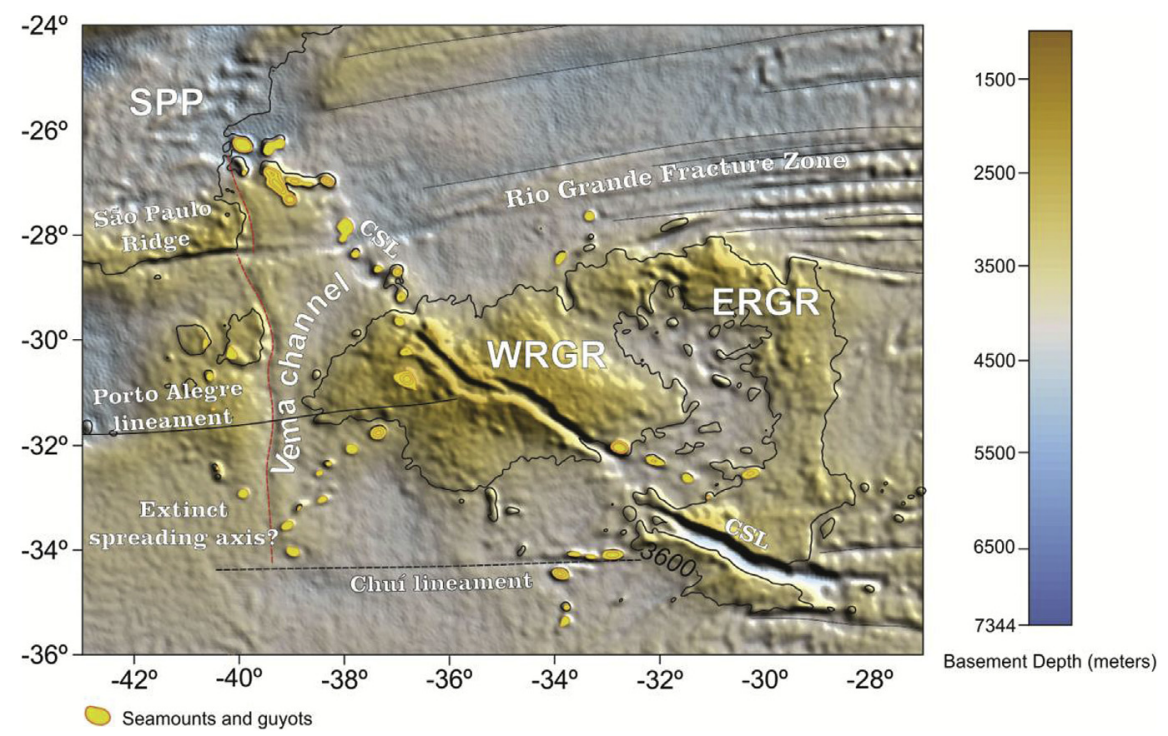

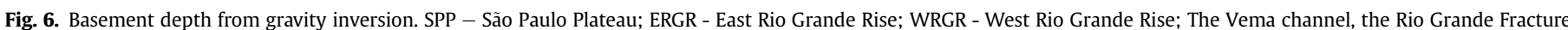

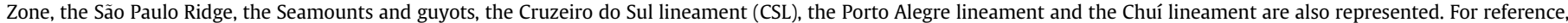
the bathymetric isoline of $3600 \mathrm{~m}$ is show.
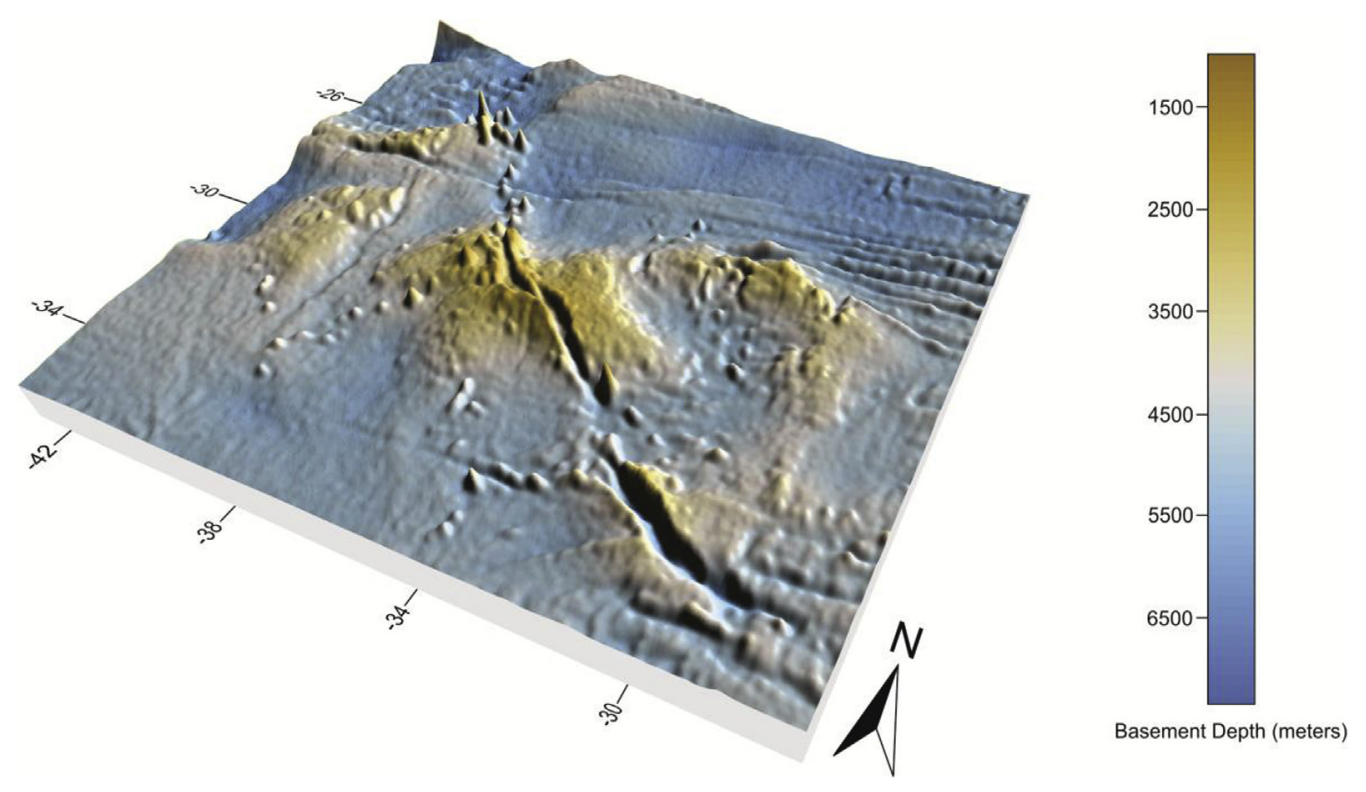

Fig. 7. Basement depth from gravity inversion: 3D relief map.

The basement topography is strongly dependent on the sediment model below the São Paulo Plateau (SPP), where the sedimentation is higher, and less (but still dependent) under the Rio Grande Rise (RGR), where the sediment is thinner. Neglecting the sediments has the effect of underestimating the basement depth. Nonetheless, short-wavelength features of the basement can be recovered from the gravity data without taking into account the sediment model, in areas where the latter is unavailable (Braitenberg et al., 2006). The gravity effect of the sediments included in the model was calculated considering a linear compaction with depth, however, we also calculated for an exponential compaction following the methodology proposed by Sclater and Christie (1980). On both cases, the results were compared to the DSDP density values and the best fit was found for the linear compaction.

A result of our analysis is the Moho interface depth that best fit to the seismic constraining Moho depths and the gravity field. We have used a constant density contrast along the interface, which acts as a linear scaling parameter with respect to the reference depth. This cannot be considered a problem since the achieved results are very similar from the seismic constrained data. A RMS error of $1.17 \mathrm{~km}$ between the modeled Moho and seismic constrains was found. However, areas where data is available, a variable density contrast can be used to make a correction to the model.

The Moho depth is greater under de SPP and under the RGR, reaching depths up to $28 \mathrm{~km}$. This depth values seems to agree with previous works (e.g., Zalán et al., 2011; Ussami et al., 2012). 


\section{Conclusion}

We have shown that from satellite-derived gravity field, bathymetry and sediment thicknesses, it is possible to give a 3-D model of the basement over oceanic areas, and for this purpose, we have chosen the Rio Grande Rise, in South Atlantic Ocean, to build a gravity-equivalent basement topography.

The advantages of the method are manifold: does not depend directly on reflection seismic data; can be applied quickly and with fewer costs for acquiring and interpreting the data; and as the main result, presents the physical surface below the sedimentary layer, which may be different from the acoustic basement.

A description of the basement over Rio Grande Rise area is unprecedented in the literature, however, our results could be compared to in situ data, provided by Deep Sea Drilling Program, and a small difference of only $9 \mathrm{~m}$ between our basement depth and leg $516 \mathrm{~F}$ was found

Seamounts, guyots and fracture zones are much more clearly defined in the basement than in the bathymetric model, as well as it reveals short-wavelength features. A NS structure that has not been presented previously in the literature is interpreted in the basement model, and we propose that this feature could reveal an extinct spreading center. However, for a better understanding, a new study with a more geological focus should be carried out.

The ocean bottom is flat when compared to the gravity field, indicating that some tectonic features have been buried by sediments. In places where the coherence between the gravity anomaly and the bathymetry is low, this method could be used to extract concealed features of the basement. The methodology has already been successfully tested in the South China Sea, Santos Basin and now in the Rio Grande Rise. This shows that is a reliable method that can be applied in other oceanic areas of the world.

\section{Acknowledgments}

We acknowledge support from CAPES, in particular CAPES/IODP Proc. 88887.091710 2014-01 for financial support and for the postdoctoral fellowship of Renata Constantino. Geological Survey of Brazil (CPRM) for providing data to this research. Dr. Carlos Eduardo Ganade de Araújo for implementing knowledge and discussing our study. Prof. Dr. Eder Cassola Molina for supporting with gravimetric interpretation. Reviewers and editors for valuable suggestions.

\section{References}

Amante, C., Eakins, B.W., 2009. ETOPO1 1 Arc-minute Global Relief Model: Procedures, Data Sources and Analysis. US Department of Commerce, National Oceanic and Atmospheric Administration, National Environmental Satellite. Data, and Information Service, National Geophysical Data Center, Marine Geology and Geophysics Division, Colorado, p. 19.

Barker, P.F., 1983. Tectonic evolution and subsidence history of the rio-grande rise Initial Rep. Deep Sea Drill. Proj. 72 (DEC), 953-976.

Basseto, M., 1996. Análise morfo-estrutural do dominio oceânico da porção sulsudeste da margem continental brasileira (Doctoral dissertation).

Braitenberg, C., Pettenati, F., Zadro, M., 1997. Spectral and classical methods in the evaluation of Moho undulations from gravity data: the NE Italian Alps and isostasy. J. Geodyn. 23 (1), 5-22.
Braitenberg, C., Wienecke, S., Wang, Y., 2006. Basement structures from satellitederived gravity field: south China Sea ridge. J. Geophys. Res. Solid Earth 111 (B5).

Constantino, R., Molina, E.C., 2014. Basement Structure of the Santos Basin from Gravity Data. In Gravity, Geoid and Height Systems. Springer International Publishing, pp. 319-328.

Constantino, R.R., Molina, E.C., de Souza, I.A., 2016. Study of salt structures from gravity and seismic data in Santos Basin, Brazil. Geofísica Int. 55 (3), 199-214.

Detrick, R.S., Sclater, J.G., Thiede, J., 1977. The subsidence of aseismic ridges. Earth Planet. Sci. Lett. 34 (2), 185-196.

Divins, D.L., 2003. Total Sediment Thickness of the World's Oceans and Marginal Seas. NOAA National Geophysical Data Center, Boulder, CO.

Fodor, R.V., Husler, J.W., Kumar, N., 1977. Petrology of volcanic rocks from an aseismic rise: implications for the origin of the Rio Grande rise, South Atlantic ocean. Earth Planet. Sci. Lett. 35 (2), 225-233.

Gamboa, L.A.P., Rabinowitz, P.D., 1981. The Rio Grande fracture zone in the western South Atlantic and its tectonic implications. Earth Planet. Sci. Lett. 52 (2), 410-418.

Gamboa, L.A.P., Rabinowitz, P.D., 1984. The evolution of the Rio Grande rise in the southwest Atlantic ocean. Mar. Geol. 58 (1-2), 35-58.

Kumar, N., 1979. Origin of "paired" aseismic rises: ceará and Sierra Leone rises in the equatorial, and the Rio Grande rise and Walvis Ridge in the South atlantic. Mar. Geol. 30 (3-4), 175-191.

Kumar, N., Gamboa, L.A.P., Schreiber, B.C., Mascle, J., 1977. Geologic history and origin of sao Paulo plateau (southeastern brazilian margin), comparison with the angolan margin and the early evolution of the northern South Atlantic. D.C. Gov. Print. Off. 39, 927-945.

Leyden, R., Ludwig, W.J., Ewing, M., 1971. Structure of continental margin off Punta del Este, Uruguay, and Rio de Janeiro, Brazil. AAPG Bull. 55 (12), 2161-2173.

Mohriak, W.U., Nóbrega, M., Odegard, M.E., Gomes, B.S., Dickson, W.G., 2010 Geological and geophysical interpretation of the Rio Grande Rise, south-eastern Brazilian margin: extensional tectonics and rifting of continental and oceanic crusts. Pet. Geosci. 16 (3), 231-245.

O'Connor, J.M., Duncan, R.A. 1990. Evolution of the Walvis Ridge-Rio Grande rise hot spot system: implications for african and south american plate motions over plumes. J. Geophys. Res. Solid Earth 95 (B11), 17475-17502.

Parker, R.L., 1972. The rapid calculation of potential anomalies. Geophys. J. Int. 31 (4), 447-455

Rohde, J.K., van den Bogaard, P., Hoernle, K., Hauff, F., Werner, R., 2012. Evidence for an age progression along the Tristan-Gough volcanic track from new $40 \mathrm{Ar} / 39$ Ar ages on phenocryst phases. Tectonophysics 604, 60-71.

Russo, R.M., Speed, E.R., 1994. Spectral analysis of gravity anomalies and the architecture of tectonic wedging, NE Venezuela and Trinidad. Tectonics 13 (3), $613-622$.

Sandwell, D.T., Smith, W.H.F., 2001. Bathymetric estimation. In: Fu, L.-L., Cazenave, A. (Eds.), Satellite Altimetry and Earth Sciences. Elsevier, New York, pp. $441-457$.

Sandwell, D.T., Müller, R.D., Smith, W.H., Garcia, E., Francis, R., 2014. New global marine gravity model from CryoSat-2 and Jason-1 reveals buried tectonic structure. Science 346 (6205), 65-67.

Sclater, J.G., Christie, P.A.F., 1980. Continental stretching; an explanation of the postMid-Cretaceous subsidence of the central North Sea basin. J. Geophys. Res. 85 (B7), 3711-3739.

Smith, W.H., Sandwell, D.T., 1997. Global sea floor topography from satellite altimetry and ship depth soundings. Science 277 (5334), 1956-1962.

Thompson, G., Humphris, S., Schilling, J.G., 1983. Petrology and geochemistry of basaltic rocks from rio-grande rise, south-atlantic-deep-sea drilling project LEG-72, HOLE-516F. Initial Rep. Deep Sea Drill. Proj. 72 (DEC), 457-466.

Ussami, N., Chaves, C.A.M., Marques, L.S., Ernesto, M., 2012. Origin of the Rio Grande Rise-Walvis Ridge reviewed integrating paleogeographic reconstruction, isotope geochemistry and flexural modelling. Geol. Soc. Lond. Spec. Publ. 369 (1), 129-146.

Wienecke, S., Mariani, P., Ebbing, J., 2008. LithoFLEX tutorial. Available in http:// www.lithoflex.org/lithoflex/home/basics/Lithoflex_tutorial.pdf.

Zalán, P.V., Severino, M.D.C.G., Rigoti, C.A., Magnavita, L.P., Oliveira, J.A.B. Vianna, A.R., 2011, April. An entirely new 3D-view of the crustal and mantle structure of a South Atlantic passive margin-Santos, Campos and Espírito Santo basins, Brazil. In: Americal Association of Petroleum Geology, Annual Convention and Exhibition. 